\title{
ALUR PEMERIKSAAN SENGKETA TATA USAHA NEGARA MELALUI UPAYA ADMINISTRATIF
}

\author{
JOHNNY FAKHRIZAL \\ johnnyfakhrizal@gmail.com \\ 1910003600178 \\ UNIVERSITAS EKASAKTI - AAI PADANG
}

\section{A. PENDAHULUAN}

Dalam pelaksanaan tugas administrasi pemerintahan yang baik yang menyangkut urusan eksternal (pelayanan umum) maupun yang berkaitan dengan urusan internal (seperti urusan kepegawaian), suatu instansi pemerintah (Badan/Pejabat TUN) tidak dapat dilepaskan dari tugas pembuatan Keputusan Tata Usaha Negara. Dengan semakin kompleksnya urusan pemerintahan serta semakin meningkatnya pengetahuan dan kesadaran masyarakat, tidak tertutup kemungkinan timbulnya benturan kepentingan (Conflict of Interest) antara pemerintah (Badan/Pejabat TUN) dengan seseorang/Badan Hukum Perdata yang merasa dirugikan oleh Keputusan Tata Usaha Negara tersebut, sehingga menimbulkan suatu sengketa Tata Usaha Negara.

Penyelesaian sengketa Tata Usaha Negara sebagai akibat terjadinya benturan kepentingan antara pemerintah (Badan/Pejabat TUN) dengan seseorang/ Badan Hulum Perdata tersebut, ada kalanya dapat diselesaikan secara damai melalui musyawarah dan mufakat, akan tetapi ada kalanya pula berkembang menjadi sengketa hukum yang memerlukan penyelsaian lewat pengadilan.

Sebagai Negara yang berdasarkan atas hukum (rechtstaat), maka timbulnya suatu sengketa Tata Usaha Negara tersebut, bukanlah hal yang harus dianggap sebagai hambatan pmerintah (Badan/Pejabat TUN) dalam melaksanakan tugas dibidang urusan pemerintah, melainkan harus dipandang sebagai : 
1. Dari sudut pandang warga masyarakat, adalah merupakan pengejawantahan asas Negara hukum bahwa setiap warga Negara dijamin hak-haknya menurut hukum, dan segala penyelesaian sengketa harus dapat diselesaikan secara hukum pula

2. Dari sudut pandang Badan/Pejabat TUN, adalah sarana atau forum untuk menguji apakah Keputusan Tata Usaha Negara yang diterbitkannya telah memenuhi asas-asas hukum dan keadilan melalui sarana hukum menurut peraturan perundang-undangan yang berlaku.

Oleh karena itu lahirnya suatu senketa Tata Usaha Negara bukanlah suatu hal yang luar biasa, melainkan suatu hal yang harus diselesaikan dan dicari jalan penyelesaiannya melalui sarana yang disediakan oleh peraturan perundang-undangan yang berlaku.

Menurut Undang-Undang No. 5 Tahun 1985 jo Undang-Undang No. 9 Tahun 2004 tentang Peradilan Tata Usaha Negara, untuk menyelesaikan sengketa Tata Usaha Negara yang timbul sebagai akibat diterbitkannya suatu Keputusan Tata Usaha Negara (Beschikking) dapat dilakukan melalui 2 (dua) cara, yaitu antara lain :

1. Melalui upaya administrasi (Vide Pasal 48 jo Pasal 51 ayat (3)

2. Melalui gugatan (Vide pasal 1 angka 5 jo pasal 53).

Makalah ini ditulis untuk menjelaskan lebih lanjut mengenai pengertian, dasar hukum, bentuk dan proses penyelesaian sengketa Tata Usaha Negara melalui upaya administrasi.

\section{B. PEMBAHASAN}

Sebelum menguraikan lebih lanjut mengenai upaya administrasi, terlebih dahulu akan dibahas apa yang dimaksud dengan sengketa Tata Usaha Negara, Keputusan Tata Usaha Negara dan hal-hal yang berkaitan dengan Keputusan Tata Usaha Negara tersebut.

Menurut ketentuan Pasal 1 angka 4 Undang-Undang No. 5 Tahun 1986 jo UndangUndang No. 9 Tahun 2004 tentang Peradilan Tata Usaha Negara, sengketa TUN adalah sengketa 
yang timbul antara orang atau Badan Hukum perdata baik di pusat maupun di daerah, sebagai akibat dikeluarkan Keputusan Tata Usaha Negara, termasuk sengketa kepegawaian berdasarkan peraturan perundang-undangan yang berlaku.

Sedangkan Keputusan Tata Usaha Negara menurut ketentuan pasal 1 angka (3) UndangUndang No. 5 Tahun 1986 jo Undang-Undang No. 9 Tahun 2004 tentang Peradilan Tata Usaha Negara adalah suatu penetapan tertulis yang dikeluarkan oleh Badan/Pejabat Tata Usaha Negara yang berisi tindakan hukum Tata Usaha Negara berdasarkan peraturan perundang-undangan yang berlaku, yang bersifat konkrit, individual dan final yang menimbulkan akibat hukum bagi seseorang atau badan hukum perdata.

Dari rumusan pasal tersebut, ternyata Keputusan Tata Usaha Negara yang merupakan dasar lahirnya sengketa Tata Usaha Negara mempunyai cirri-ciri sebagai berikut :

1. Penetapan tertulis

2. Dikeluarkan oleh Badan/Pejabat Tata Usaha Negara

3. Berisi tindakan hukum Tata Usaha Negara

4. Berdasarkan peraturan perundang-undangan yang berlaku

5. Bersifat konkrit, individual dan final

6. Menimbulkan akibat hukum bagi seseorang atau badan hukum perdata.

Ke-6 (enam) elemen tersebut bersifat komulatif, artinya untuk dapat disebut Keputusan Tata Usaha Negara yang dapat disengketakan di Pengadilan Tata Usaha Negara harus memenuhi keseluruhan elemen tersebut. Jenis-jenis Keputusan Tata Usaha Negara/ KTUN (Beschikking) menurut doktrin (pendapat/ teori para pakar administrasi Negara) terdapat berbagai rumusan, antara lain menurut P. De Haan (Belanda), dalam bukunya : "Bestuursrecht in de Sociale Rechtsstaat”, (Philipus M. Hadjon; 2002) dikelompokkan sebagai berikut :

1. KTUN Perorangan dan Kebendaan (Persoonlijk en Zakelijk) 
- KTUN perorangan adalah keputusan yang diterbitkan kepada seseorang berdasarkan kualitas pribadi tertentu, dimana hak yang timbul tidak dapat dialihkan kepada orang lain. Contoh : SK PNS, SIM,dsb.

KTUN kebendaan adalah keputusan yang diterbitkan berdasarkan kualitas kebendaan atau status suatu benda sebagai obyek hak, dimana hak yang timbul dapat dialihkan kepada orang lain. Contoh : Sertipikat Hak atas Tanah, BPKP/STNK kendaraan bermotor, dsb.

2. KTUN Deklaratif dan Konstitutif (Rechtsvastellend en Rechtsscheppend)

KTUN deklaratif adalah keputusan yang sifatnya menyatakan atau menegaskan adanya hubungan hukum yang secara riil sudah ada. Contoh : Akta Kelahiran, Akta Kematian, dsb.

KTUN konstitutif adalah keputusan yang menciptakan hubungan hukum baru yang sebelumnya tidak ada, atau sebaliknya memutuskan hubungan hukum yang ada. Contoh : Akta Perkawinan, Akta Perceraian, dsb

3. KTUN Bebas dan Terikat (Vrij en Gebonden)

KTUN bebas adalah keputusan yang didasarkan atas kebebasan bertindak (Freis Ermessen/ Discretionary Power) dan memberikan kebebasan bagi pelaksananya untuk melakukan penafsiran atau kebijaksanaan.

Contoh : SK Pemberhentian PNS yang didasarkan hukuman disiplin yang telah diatur secara jelas dan rinci di dalam perundang-undangan.

4. KTUN yang member beban dan yang menguntungkan (Belastend en Begunstigend)

$>$ KTUN yang member beban adalah keputusan yang memberikan kewajiban.

Contoh : SK tentang Pajak, Restribusi, dll 
$>$ KTUN yang menguntungkan adalah keputusan yang memberikan keuntungan bagi pihak yang dituju. Contoh : SK pemutihan pembayaran pajak yang telah kadaluwarsa.

5. KTUN Seketika dan Permanen (Einmaligh en Voortdurend).

KTUN seketika adalah keputusan yang masa berlakunya hanya sekali pakai. Contoh : Surat ijin pertunjkan hiburan, music, olahraga, dll

KTUN pemanen adalah keputusan yang masa berlakunya untuk selama-lamanya, kecuali ada perubahan atau peraturan baru. Contoh : Sertipikat Hak Miik

Sedangkan menurut Undang-Undang No. 5 Tahun 1986 jo Undang-Undang No. 9 Tahun 2004 tentang Peradilan Tata Usaha Negara:

1. Keputusan Tata Usaha Negara Positif (Pasal 1 angka (3)

Yaitu penetapan tertulis yang dikeluarkan oleh Badan/Pejabat Tata Usaha Negara yang berisi tindakan hukum Tata Usaha Negara yang berdasarkan peraturan perundangundangan yang berlaku, bersifat konkrit, individual dan final yang menimbulkan akibat hukum bagi seseorang atau Badan Hukum Perdata.

2. Keputusan Tata Usaha Negara Fiktif (Pasal 3 angka (1)) Yaitu keputusan Tata Usaha Negara yang seharusnyadikeluarkan oleh Badan/Pejabat Tata Usaha Negara menurut kewajibannya tetapi ternyata tidak diterbitkan, sehingga menimbulkan kerugian bagi seseorang atau Badan Hukum Perdata.

Contoh : Dalam kasus kepegawaian, seorang atasan berkewajiban membuat DP3 atau mengusulkan kenaikan pangkat bawahannya, tetapi atasannya tidak melakukan.

3. Keputusan Tata Usaha Negara Fiktif Negatif (Pasal 3 ayat (2)

Yaitu keputusan Tata Usaha Negara yang dimohonkan seseorang atau Badan Hukum Perdata, tetapi tidak ditanggapi atau tidak diterbitkan oleh Badan/Pejabat Tata Usaha 
Negara yang bersangkutan. Sehingga dianggap bahwa Badan/Pejabat Tata Usaha Negara telah mengeluarkan keputusan penolakan (negatif).

Contoh : Pemohon IMB, KTP, Sertipikat, dsb apabila dalam jangka waktu yang ditentukan tidak dijawab/diterbitkan, maka dianggap jelas-jelas menerbitkan keputusan Tata Usaha Negara yang menolak.

Dalam praktek administrasi pemerintahan terdapat beberapa KTUN yang berpotensi menimbulkan sengketa Tata Usaha Negara, yaitu antara lain :

1) Keputusan tentang perijinan

Secara yuridis suatu ijin adalah merupakan persetujuan yang diberikan pemerintah (Badan/Pejabat TUN) kepada seseorang atau Badan Hukum Perdata untuk melakukan aktivitas tertentu. Menurut Philipus M. Hadjon tujuan diadakannya perijinan pada pokoknya adalah untuk :

a. Mengarahkan atau mengendalikan aktivitas tertentu (missal : ijin prinsip, IMB, ijin pertambangan, ijin pengusahaan hutan, ijin berburu, dsb)

b. Mencegah bahaya atau gangguan (missal : gangguan/ Hinder Ordanatie, amdal, dsb)

c. Melindungi obyek tertentu (missal : ijin masuk obyek wisata, cagar budaya, dsb)

d. Distribusi benda atau barang langka (missal : ijin trayek, ijin perdagangan satwa langka, dsb)

e. Seleksi orang atau aktivitas tertentu (missal : SIM, ijin memiliki senjata api, ijin penelitian, dsb).

2) Keputusan tentang status hukum, hak dan kewajiban

> Status hukum perorangan atau badan hukum, misalnya akta kelahiran, akta kematian, akta pendirian/pembubaran badan hukum, KTP, Ijasah, sertipikat (Tanda Lulus Ujian), dll. 
Hak/ kewajiban perorangan atau badan hukum terhadap suatu barang atau jasa, misalnya pemberian/pencabutan hak atas tanah, hak untuk melakukan pekerjaan, dsb.

3) Keputusan tentang kepegawaian.

Keputusan tentang mutasi PNS, dimana pegawai yang dimutasi keberatan karena merasa dirugikan, menghambat karier atau karena mutasi itu dianggap sebagai hukuman disiplin terselubung

Keputusan tentang hukuman disiplin PNS, dimana pegawai yang bersangkutan menganggap hukuman itu tidak sesuai dengan prosedur atau tidak adil

Keputusan tentang pemberhentian PNS, misalnya dalam rangka perampingan pegawai atau likuidasi suatu instansi, dsb.

Menurut ketentuan pasal 35 Undang-Undang No. 43 Tahun 1999 tentang Perubahan atas Undang-Undang No. 8 tahun 1974 tentang Pokok-Pokok Kepegawaian:

1) Sengketa kepegawaian diselesaikan melalui Peradilan Tata Usaha Negara

2) Sengketa kepegawaian sebagai akibat pelanggaran terhadap peraturan disiplin PNS diselesaikan melalui upaya banding administratif kepada Badan Pertimbangan Kepegawaian (BAPEG).

\section{PENGERTIAN UPAYA ADMINISTRASI}

Menurut Penjelasan pasal 48 Undang-Undang No. 5 Tahun 1986 jo Undang-Undang No. 9 Tahun 2004 tentang Peradilan Tata Usaha Negara, upaya administratif adalah merupakan prosedur yang ditentukan dalam suatu peraturan perundang-undangan untuk menyelesaikan suatu sengketa Tata Usaha Negara yang dilaksanakan dilingkungan pemerintah sendiri (bukan oleh badan peradilan yang bebas), yang terdiri dari :

a. Prosedur keberatan 
b. Prosedur banding administratif

Berdasarkan rumusan penjelasan pasal 48 tersebut maka upaya administratif merupakan sarana perlindungan hukum bagi warga masyarakat (orang perorangan/badan hukum perdata) yang terkena Keputusan Tata Usaha Negara (Beschikking) yang merugikannya melalui Badan/Pejabat Tata Usaha Negara dilingkungan pemerintah itu sendiri sebelum diajukan ke badan peradilan.

\section{DASAR HUKUM UPAYA ADMINISTRASI}

Dalam pasal 48 Undang-Undang No. 5 Tahun 1986 jo UndangUndang No. 9 Tahun 2004 tentang Peradilan Tata Usaha Negara, disebutkan sebagai berikut :

1) Dalam hal suatu Badan/Pejabat Tata Usaha Negara diberi wewenang oleh atau berdasarkan peraturan perundang-undangan untuk menyelesaikan secara administratif sengketa Tata Usaha Negara tertentu, maka sengketa Tata Usaha Negara tersebut harus diselesaikan melalui upaya administratif yang tersedia.

2) Pengadilan baru berwenang memeriksa, memutus, dan menyelesaikan sengketa Tata Usaha Negara sebagaimana dimaksud ayat (1) jika seluruh upaya administratif yang bersangkutan telah digunakan.

\section{BENTUK UPAYA ADMINISTRASI DAN CARA PENGUJIANNYA}

Berdasarkan penjelasan pasal 48 Undang-Undang No. 5 Tahun 1986 jo Undang-Undang No. 9 Tahun 2004 tentang Peradilan Tata Usaha Negara, bentuk upaya administrasi ada 2 (dua) yaitu :

1. Banding administrasi

2. Keberatan

Ad : 
1) Banding administrasi; Apabila penyelesaian sengketa Tata Usaha Negara tersbut dilakukan oleh instasi lain dari Badan/Pejabat Tata Usaha Negara yang menerbitkan Keptusan Tata Usaha Negara yang bersangkutan.

Contoh :

$>$ Keputusan Badan Pertimbangan Kepegawaian (BAPEK) berdasarkan No. 30 Tahun 1980 tentang Disiplin PNS.

$>$ Keputusan Panitia Penyelesaian Perselisihan Perburuhan Pusat (P4P) berdasar Undang-Undang No. 22 Tahun 1957 tentang Penyelesaian Perburuhan dan UndangUndang No. 12 Tahun 1964 tentang Pemutusan Hubungan Kerja di Perusahaan Swasta.

$>$ Keputusan Gubernur, berdasar pasal 10 ayat (2) Undang-Undang Gangguan, Staasblad 1926 No. 226.

$>$ Keputusan Panitia Tenaga Kerja Migas di lingkungan Departemen Pertambangan bagi perusahaan minyak dan gas bumi (PERTAMINA).

> Komisi Banding Paten berdasarkan PP No. 31 Tahun 1995, sehubungan dengan adanya Undang-Undang No. 6 Tahun 1989 tentang Paten.

> Komisi Banding Merek berdasarkan PP No. 32 Tahun 1995, sehubungan dengan adanya Undang-Undang No. 19 Tahun 1992 tentang Merek.

Majelis Pertimbangan Pajak sebagai banding administrasi perpajakan.

$>$ Dengan berkembangnya perusahaan-perusahaan milik Negara dari PERJAN dan PERUM menjadi PERSERO (BUMN) tersebut membuat ketentuan sendiri tentang operasional, kepegawaian, dll. 
2). Keberatan ; Apabila penyelesaian sengketa Tata Usaha Negara tersebut harus dilakukan sendiri oleh Badan/Pejabat Tata Usaha Negara yang mengeluarkan Keputusan Tata Usaha Negara tersebut.

Contoh :

> Pasal 27 Undang-Undang No. 9 Tahun 1994 tentang ketentuanKetentuan Umum Perpajakan;

$>$ Pemberian hukuman disiplin sedang dan berat (selain pemberhentian dengan hormat dan tidak dengan hormat bagi (PNS).

Pengujian (Toetsing) dalam upaya administrasi berbeda dengan pengujian di Peradilan Tata Usaha Negara. Di Peradilan Tata Usaha Negara pengujiannya hanya dari segi penerapan hukum sebagaimana ditentukan pasal 53 ayat (2) huruf (a) dan (b) Undang-Undang No. 9 Tahun 2004 tentang perubahan atas Undang-Undang No. 5 Tahun 1986 tentang Peradilan Tata Usaha Negara, yaitu apakah keputusan Tata Usaha Negara tersebut diterbitkan dengan bertentangan dengan peraturan perundang-undangan yang berlaku dan melanggar Asas-Asas Umum Pemerintah Yang Baik (AAUPB), sedangkan pada prosedur upaya administrasi, pengujiannya dilakukan baik dari segi penerapan hukum maupun dari segi kebijaksanaan oleh instansi yang memutus, sehingga pengujiannya dilakukan secara lengkap.

Sisi positif upaya administrasi yang melakukan penilaian secara lengkap suatu Keputusan Tata Usaha Negara baik dari segi Legalitas (Rechtmatigheid) maupun aspek Opportunitas (Doelmatigheid), para pihak tidak dihadapkan pada hasil keputusan menang atau kalah (Win or Loose) seperti halnya di lembaga peradilan, tapi denganpendekatan musyawarah. Sedangkan sisi negatifnya dapat terjadi pada tingkat obyektifitas penilaian karena Badan/Pejabat tata Usaha Negara yang menerbitkan Surat Keputusan kadang-kadang terkait kepentingannya secara 
langsung ataupun tidak langsung sehingga mengurangi penilaian maksimal yang seharusnya ditempuh.

Tidak semua peraturan dasar penerbitan Keputusan Tata Usaha Negara mengatur mengenai upaya administrasi, oleh karena itu adanya ketentuan pasal 48 Undang-Undang No. 5 Tahun 1986 jo UndangUndang No. 9 Tahun 2004 tentang Peradilan Tata Usaha Negara merupakan aspek prosedural yang sangat penting yang berkaitan dengan kompetensi atau wewenang untuk mengadii sengketa Tata Usaha Negara.

Berdasarkan Surat Edaran Mahkamah Agung RI No. 2 tahun 1991 tentang Petunjuk Pelaksanaan Ketentuan Dalam Undang-Undang No. 5 Tahun 1986 tentang Peradilan Tata Usaha Negara, disebutkan : IV.1. Yang dimaksud Upaya Adiministratif adalah :

a. Pengajuan surat keberatan (Bezwaarscriff Beroep) yang diajukan kepada Badan/Pejabat Tata Usaha Negara yang mengeluarkan Keputusan (Penetapan/ Beschikking) semula;

b. Pengajuan banding administratif (administratif Beroep) yang ditujukan kepada atasan Pejabat atau instansi lain dari Badan/Pejabat Tata Usaha Negara yang mengeluarkan keputusan yang berwenang memeriksa ulang keputusan Tata Usaha Negara yang disengketakan.

IV.2. a. Apabila peraturan dasarnya hanya menentukan adanya upaya administratif berupa peninjauan surat keberatan, maka gugatan terhadap Keputusan Tata Usaha Negara yang bersangkutan diajukan kepada pengadilan Tata Usaha Negara; b. Apabila peraturan dasarnya menentukan adanya upaya adiministratif berupa surat keberatan dan atau mewajibkan surat banding administratif, maka gugatan terhadap Keputusan Tata Usaha Negara yang telah diputus dalam tingkat banding administratif diajukan langsung kepada Pengadilan Tinggi Tata Usaha Negara dalam tingkat pertama yang berwenang. 
Ketentuan tersebut sesuai pula dengan ketentuan yang diatur dalam pasal 48 ayat (2) yang menyatakan "pengadilan baru berwenang memeriksa, menyelesaikan sengketa Tata Usaha Negara sebagaimana dimaksud dalam ayat (1) jika seluruh upaya administratif yang bersangkutan telah digunakan " jo ketentuan pasal 51 ayat (3) ditentukan bahwa dalam hal suatu sengketa dimungkinkan adanya administratif maka gugatan langsung ditujukan kepada Pengadilan Tinggi Tata Usaha Negara apabila keputusannya merupakan keputusan banding administratif.

\section{PENUTUP}

Berdasarkan uraian tersebut diatas, maka dapat disimpulkan hal-hal sebagai berikut :

1. Apakah suatu sengketa Tata Usaha Negara harus diselesaikan melalui upaya administrasi atau tidak, adalah tergantung pada peraturan perundang-undangan yang menjadi dasar mengeluarkan keputusan Tata Usaha Negara tersebut.

2. Istilah upaya administratif hanya ada dalam Undang-Undang No. 5 tahun 1986 jo Undang-Undang No 9 Tahun 2004 tentang Peradilan Tata Usaha Negara, sedangkan peraturan perundangundangan memakai istilan yang bermacam-macam;

3. Untuk membedakan apakah sengketa harus diselesaikan melalui banding administratif atau keberatan dapat dilihat dari pejabat atau instansi yang berwenang menyelasaikannya;

a. Apabila diselesaikan oleh instansi atasan Pejabat yang menerbitkan Keputusan Tata Usaha Negara tersebut atau instansi yang lainnya dari Badan/Pejabat Tata Usaha Negara yang menerbitkan Keputusan Tata Usaha Negara, maka penyelesaiannya tersebut disebut dengan "BANDING ADMINISTRATIF"; 
b. Apabila diselesaikan instansi atau Pejabat yang mengeluarkan keputusan Tata Usaha Negara tersebut, penyelesaian tersebut disebut dengan "KEBERATAN".

4. Cara pengujian penyelesaian melalui upaya administratif adalah dilakukan secara lengkap dalam arti dari segi hukum dan kebijaksanaan, sedangkan pengujian di Pengadilan hanya dari segi hukumnya saja;

5. Dalam hal masih tidak puas terhadap penyelesaian melalui upaya administratif, maka dapat ditempuh upaya antara lain :

a. Setelah melalui upaya administratif maka dapat diajukan gugatan ke Pengadilan Tinggi Tata Usaha Negara sebagai pengadilan tingkat pertama;

b. Setelah melalui upaya keberatan, maka dapat diajukan ke Pengadilan Tata Usaha Negara.

\section{DAFTAR PUSTAKA}

Darmini Roza dan Laurensius Arliman S Peran Pemerintah Daerah Di Dalam Melindungi Hak Anak Di Indonesia, Masalah-Masalah Hukum, Volume 47, Nomor 1, 2018.

Laurensius Arliman S, Komnas HAM dan Perlindungan Anak Pelaku Tindak Pidana, Deepublish, Yogyakarta, 2015.

Laurensius Arliman S, Penguatan Perlindungan Anak Dari Tindakan Human Trafficking Di Daerah Perbatasan Indonesia, Jurnal Selat, Volume 4, Nomor 1, 2016.

Laurensius Arliman S, Problematika Dan Solusi Pemenuhan Perlindungan Hak Anak Sebagai Tersangka Tindak Pidana Di Satlantas Polresta Pariaman, Justicia Islamica, Volume 13, Nomor 2, 2016.

Laurensius Arliman S, Pelaksanaan Perlindungan Anak Yang Tereksploitasi Secara Ekonomi Oleh Pemerintah Kota Padang, Veritas et Justitia, Volume 2, Nomor 1, 2016.

Laurensius Arliman S, Kedudukan Ketetapan MPR Dalam Hierarki Peraturan PerundangUndangan Di Indonesia, Lex Jurnalica, Volume 13, Nomor 3, 2016.

Laurensius Arliman S, Komnas Perempuan Sebagai State Auxialiary Bodies Dalam Penegakan Ham Perempuan Indonesia, Justicia Islamica, Volume 14, Nomor 2, 2017. 
Laurensius Arliman S, Peranan Pers Untuk Mewujudkan Perlindungan Anak Berkelanjutan Di Indonesia, Jurnal Ilmu Hukum Tambun Bungai, Volume 2, Nomor 2, 2017.

Laurensius Arliman S, Mewujudkan Penegakan Hukum Yang Baik Untuk Mewujudkan Indonesia Sebagai Negara Hukum, Jurnal Hukum Doctrinal, Volume 2, Nomor 2, 2017.

Laurensius Arliman S, Participation Non-Governmental Organization In Protecting Child Rights In The Area Of Social Conflict, The 1st Ushuluddin and Islamic Thought International Conference (Usicon), Volume 1, 2017.

Laurensius Arliman S, Partisipasi Masyarakat Dalam Pembentukan Perundang-Undangan Untuk Mewujudkan Negara Kesejahteraan Indonesia, Jurnal Politik Pemerintahan Dharma Praja, Volume 10, Nomor 1, 2017, https://doi.org/10.33701/jppdp.v10i1.379.

Laurensius Arliman S, Peran Komisi Perlindungan Anak Indonesia Untuk Mewujudkan Perlindungan Anak, Jurnal Respublica Volume 17, Nomor 2, 2018.

Laurensius Arliman S, Menjerat Pelaku Penyuruh Pengrusakan Barang Milik Orang Lain Dengan Mempertimbangkan Asas Fungsi Sosial, Jurnal Gagasan Hukum, Volume 1, Nomor 1, 2019.

Laurensius Arliman S, Ilmu Perundang-Undangan Yang Baik Untuk Negara Indonesia, Deepublish, Yogyakarta, 2019.

Laurensius Arliman S, Isdal Veri, Gustiwarni, Elfitrayenti, Ade Sakurawati, Yasri, Pengaruh Karakteristik Individu, Perlindungan Hak Perempuan Terhadap Kualitas Pelayanan Komnas Perempuan Dengan Kompetensi Sumber Daya Manusia Sebagai Variabel Mediasi, Jurnal Menara Ekonomi: Penelitian dan Kajian Ilmiah Bidang Ekonomi, Volume 6, Nomor 2, 2020.

Laurensius Arliman S, Pendidikan Kewarganegaraan, Deepublish, Yogyakarta, 2020.

Laurensius Arliman S, Makna Keuangan Negara Dalam Pasal Pasal 23 E Undang-Undang Dasar 1945, Jurnal Lex Librum, Volume 6, Nomor 2 Juni 2020, http://dx.doi.org/10.46839/1ljih.v6i2.151.

Laurensius Arliman S, Kedudukan Lembaga Negara Independen Di Indonesia Untuk Mencapai Tujuan Negara Hukum, Kertha Semaya Journal Ilmu Hukum, Volume 8, Nomor 7, 2020.

Laurensius Arliman S, Pelaksanaan Assesment Oleh Polres Kepulauan Mentawai Sebagai Bentuk Pelaksanaan Rehabilitasi Bagi Pecandu Dan Korban Penyalahgunaan Narkotika, Jurnal Muhakkamah, Volume 5, Nomor 1, 2020.

Laurensius Arliman S, Aswandi Aswandi, Firgi Nurdiansyah, Laxmy Defilah, Nova Sari Yudistia, Ni Putu Eka, Viona Putri, Zakia Zakia, Ernita Arief, Prinsip, Mekanisme Dan Bentuk Pelayanan Informasi Kepada Publik Oleh Direktorat Jenderal Pajak, Volume 17, No Nomor, 2020. 
Larensius Arliman S, Koordinasi PT. Pegadaian (Persero) Dengan Direktorat Reserse Narkoba Polda Sumbar Dalam Penimbangan Barang Bukti Penyalahgunaan Narkotika, UIR Law Review, Volume 4, Nomor 2, 2020, https://doi.org/10.25299/uirlrev.2020.vol4(1).3779.

Laurensius Arliman S, Tantangan Pendidikan Kewarganegaraan Pada Revolusi 4.0, Ensiklopedia Sosial Review, Volume 2, Nomor 3, 2020.

Muhammad Afif dan Laurensius Arliman S, Protection Of Children's Rights Of The Islamic And Constitutional Law Perspective Of The Republic Of Indonesia, Proceeding: Internasional Conference On Humanity, Law And Sharia (Ichlash), Volume 1, Nomor 2, 2020.

Otong Rosadi danLaurensius Arliman S, Urgensi Pengaturan Badan Pembinaan Idelogi Pancasila Berdasarkan Undang-Undang Sebagai State Auxiliary Bodies yang Merawat Pancasila dalam Perspektif Hak Asasi Manusia, Prosiding Konferensi Nasional Hak Asasi Manusia, Kebudayaan dan Tujuan Pembangunan Berkelanjutan Indonesia pada Masa Pandemi Covid-19: Tantangan untuk Keilmuan Hukum dan Sosial Volume 1, Universitas Pancasila, Jakarta, 2020. 